\title{
EFEKT IVITAS PERATURAN DAERAH KABUPATEN BANGLI NOMOR 15 TAHUN 2011 TENTANG PAJAK HOTEL
}

\author{
I Wayan Geng Krisna \\ Fakultas Hukum, Universitas warmadewa, Denpasar - Bali, Indonesia
}

\begin{abstract}
Abstrak
Pajak hotel memiliki peran yang penting dalam mendorong pembangunan daerah dan meningkatkan pendapatan as li daerah di Kabupaten Bangli. Penelitian ini bertujuan untuk mengetahui efektifitas Peraturan Daerah kabupaten Bangli Nomor 15 tahun 2011 tentang pajak hotel dan juga untuk mengetahui upaya peningkatan Pendapatan Asli Daerah yang dilakukan oleh pemerintah Kabupaten Bangli dalam pelaksanaa Peraturan Daerah Nomor 15 Tahun 2011 Tentang Pajak Hotel. Penelitian ini menggunakan penelitian hukum empiris. Hasil penelitian menunjukkan bahwa 1) Efektifitas Peraturan daerah Kabupaten Bangli Nomor 15 Tahun 2011 tentang Pajak Hotel berdasarkan target realisasi pendapatan daerah Kabupaten Bangli telah berjalan efektif. Hasil ini dapat dilihat dari pencapaian target realisasi pajak di Kabupaten Bangli dalam 3 (tiga) tahun terakhir yaitu: Tahun 2017 dengan target 50.000.0000.00 realisasi 84.101.819.00 dengan persentase 168.20\%. Tahun 2018 dengan target 65.000.000.00 realisasi 73.130.121.00 dengan persentase 112.51\%. Tahun 2019 dengan target 80.000 .000 .00 realisasi 142.655.151.40 dengan persentase $178.32 \%$. 2) Upaya peningkatan pemungutan pajak hotel yang dilakukan oleh Badan Keuangan Pendapatan dan Aset Daerah kabupaten bangli yaitu yang pertama melakukan sosialisasi langsung ke masyarakat yang kedua memberikan reawed atau penghargaan kepada wajib pajak yang telah taat melakukan kewajibannya membayar pajak yang ketiga rutin melakukan verifikasi data wajib pajak, selain itu upaya yang dilakukan oleh pemerintah Kabupaten Bangli dalam meningkatkan pemungutan pajak hotel yaitu denganmengefektifkan pemungutan pajak menggunakan surat paksa agar pemungutan pajak hotel di Kabupaten Bangli semakin meningkat dan memberikan sanksi-sanksi kepada wajib pajak apabila tidak melakukan kewajibannya membayar pajak.
\end{abstract}

Kata Kunci: Efektivitas; Peraturan Daerah; Pajak Hotel

\begin{abstract}
Hotel tax has an important role in encouraging regional development and increasing local revenue in Bangli Regency. This study aims to find out the effectiveness of the Regional Regulation ofBangli District Number 15 of 2011 concerning Hotel Taxes and also to find out the efforts to increase the Regional Original Income carried out by the Bangli Regency government in implementing Regional Regulation Number 15 of 2011 concerning Hotel Taxes. This research uses empirical legal research. The results showed that 1) The effectiveness of B angli Regency Regulation Number 15 of 2011 concerning Hotel Taxes based on the realization of Bangli Regency revenue targets has been effective. This result can be seen from the achievement of the tax realization target in Bangli Regency in the last 3 (three) years, namely: 2017 with a target of 50,000.0000.00 realization of 84,101,819.00 with a percentage of $168.20 \% .2018$ with a target of 65,000,000.00 realization of 73,130,121.00 with a percentage of $112.51 \% .2019$ with a target of 80,000,000.00 realization of 142,655,151.40 with a percentage of $178.32 \% .2$ ) Theefforts to increase hotel tax collection carried out by the Bangli Regency Regional Revenue and Asset Financial Agency are the first to conduct direct socialization to the community, the second to pro vide reawed or rewards to taxpayers who have obeyed their obligation to pay taxes, the third routinely verify taxpayer data, in addition to The effort made by the Bangli Regency Government in increasing hotel tax collection is by making effective tax collection using forced letters so that hotel tax collection in Bangli Regency is increasing and giving sanctions to taxpayers if they do not have the obligation to pay taxes.
\end{abstract}

Keywords: Effectiveness, Local Regulations, Hotel Tax

\section{PENDAHULUAN}

Pembiayaan pemerintah daerah dalam melaksanakan tugas pemerintahan dan pembangunan senantiasa memerlukan sumber penerimaan yang dapat diandalkan. Kebutuhan ini semakin dirasakan oleh daerah 
terutama sejak diberlakukannya otonomi daerah di Indonesia, yaitu mulai tanggal 1 Januari 2001. Dengan adanya otonomi daerah dipacu untuk dapat berkreasi mencari sumber penerimaan daerah yang dapat mendukung pembiayaan pengeluaran daerah.

Dari berbagai alternatif sumber penerimaan yang mungkin dipungut oleh daerah, UndangUndang tentang pemerintahan Daerah menetapkan pajak dan retribusi daerah menjadi salah sumber penerimaan yang berasal dari dalam daerah dan dapat dikembangkan sesuai dengan kondisi masingmasing daerah (Siahaan, 2010:1).

Untuk memungut pajak dan retribusi daerah pemerintah dan DPR sejak lama telah mengeluarkan undang-undang sebagai dasar hukum yang kuat. Selain itu, peraturan yang dikeluarkan pada masa pemerintahan penjajah Belanda masih ada yang tetap digunakan sampai dengan tahun 1997. Hal ini terjadi karena ketentuan peralihan Undang-Undang Dasar 1945 memang memungkinkan penerapan peraturan perundang-undangan yang ada masih tetap berlaku selama belum diadakan yang baru.

Pajak dipungut berdasarkan undang-undang atau peraturan pelaksanaannya, dan terhadap pembayar pajak tidak ada teken prestasi yang di tunjukan secara langsung, serta pemungutan pajak dapat dilakukan oleh pemerintah pusat maupun pemerintah daerah, karena itu ada istilah pajak pusat dan pajak daerah (Pudyatmoko, 2002:4).

Berdasarkan APBD tahun 2011 sektor pajak daerah memiliki peran yang semakin besar karena akan digunakan untuk membiayai penyelenggaraan pemerintah daerah dan pembangunan daerah. Pajak yang dipungut oleh pemerintah daerah (pajak daerah) yang terdiri dari pajak provinsi dan pajak kabupaten. Pemungutan pajak daerah oleh pemerintah daerah provinsi maupun kabupaten/kota diatur oleh Undang-Undang Nomor 28 Tahun 2009 Tentang Pajak Daerah dan Retribusi Daerah. Dalam Pasal 1 angka 10 "Pajak daerah yang selanjutnya disebut Pajak adalah kontribusi wajib kepada Daerah yang terutang oleh orang pribadi atau badan yang bersifat memaksa berdasarkan undang- undang, dengan tidak mendapatkan imbalan secara langsung dan digunakan untuk keperluan Daerah bagi sebesarbesarnya kemakmuran rakyat." Setelah berlakunya Undang-undang tersebut, saat ini di Indonesia khususnya didaerah, penarikan sumber daya ekonomi melalui pajak daerah dan retribusi daerah dilakukan dengan aturan hukum yang jelas yaitu dengan peraturan daerah dan keputusan kepala daerah sehingga dapat diterapkan sebagai salah satu sumber penerimaan daerah (Siahaan, 2010:5).

Seiring berjalannya waktu dengan semakin berkembangnya ekonomi di Kabupaten Bangli, khususnya bidang pariwisata, ini akan mempengaruhi bertambahnya jumlah wisatawan yang datang ke Bangli baik wisatawan lokal atau manca negara. Sehingga memiliki hubungan positif dengan meningkatnya jumlah hotel yang ada di Bangli, serta menyebabkan pertumbuhan hotel di Bangli berkembang dengan pesat. Hal ini menunjukan bahwa pajak hotel memiliki peran yang penting dalam mendorong pembangunan daerah dan meningkatkan pendapatan asli daerah di Kabupaten Bangli.

Atas dasar pertimbangan tersebut maka pemerintah Kabupaten Bangli membentuk Peraturan Daerah tentang Pajak Hotel, yaitu Peraturan Daerah Kabupaten Bangli Nomor 15 Tahun 2011 tentang Pajak Hotel. Sehingga dengan adanya Peraturan Daerah tersebut diharapkan adanya peningkatan kesadaran masyarakat dalam hal memenuhi kewajibannya sebagai Wajib Pajak guna meningkatkan Pendapatan Asli Daerah (PAD) di Kabupaten Bangli. Pajak Hotel adalah pajak atas pelayanan yang disediakan oleh hotel. Dalam perda tersebut di pasal 1 angka 8 dijelaskan pengertian Hotel, Hotel adalah fasilitas penyedia jasa penginapan/peristirahatan termasuk jasa terkait lainnya dengan dipungut bayaran, yang mencakup juga motel, losmen gubuk pariwisata, wisma pariwisata, pesanggrahan, rumah penginapan, dan sejenisnya, serta rumah kos dengan jumlah kamar lebih dari 10 (sepuluh). Agar daerah dapat menjalankan kewajiban dengan sebaik-baiknya, perlu ada sumber pendapatan daerah, sesuai dengan yang dikatakan oleh Soedjito, yaitu:

Semakin besar keuangan daerah, maka semakin besar pula kemampuan daerah untuk menyelenggarakan usaha-usahanya dalam bidang keamaan, ketertiban umum, sosial, kebudayaan, dan kesejahteraan pada umumnya bagi wilayah penduduknya, atau dengan kata lain semakin besarlah kemampuan daerah untuk memberikan pelayanan umum kepada masyarakat" (Setedi, 2008:17).

Mengingat pentingnya pajak daerah sebagai salah satu Pendapatan Asli Daerah (PAD) maka Pemerintah Kabupaten Bangli berusaha memungut pajak daerah secara profesional dan transparan berdasarkan peraturan daerah yang telah ditetapkan serta dapat mencapai target realisasi penerima an pajak daerah yang telah ditetapkan dalam rangka optimalisasi dan usaha meningkatkan kontribusi 
pengutan Pajak Hotel terhadap Anggaran Pendapatan dan Belanja Daerah (APBD) di Kabupaten Bangli.

Beberapa penelitian yang mengkaji penelitian serupa dengan penelitian sekarang ini telah dikaji sebelumnya, di antaranya (Widyaningsih, 2011); (Manus, Sabijono, \& Wangkar, 2015); (Ardiles, 2015); (Sujianto \& Andrika, 2015); (Yusmaniarti, 2017); (Zulhuda, 2017) dan (Sholihan, Kasmawanto, \& Munir, 2017). Mertayasa, Suyatna, \& Sarna (2017) mengkaji penelitian serupa berjudul "Pelaksanaan Peraturan Daerah Kabupaten Badung Nomor 15 Tahun 2011 Tentang Pajak Hotel Dalam Rangka Meningkatakan Pendapatan Asli Daerah di Kabupaten Badung". Dari hasil penelitian ini dapat dilihat bahwa pelaksanaan Peraturan Daerah Kabupaten Badung Nomor 15 Tahun 2011 tentang Pajak Hotel di Kabupaten Badung berdasarkan data realisasi penerimaan pendapatan daerah Kabupaten Badung dari pajak hotel tahun anggaran 2014 periode bulan Desember 2014 sampai dengan tahun anggaran 2016 periode bulan Desember 2016 setiap tahunnya telah mengalami peningkatan, namun secara keseluruhan pemungutan pajak hotel belum berjalan efektif karena masih terdapat piutang pajak hotel dalam jumlah yang besar yang menghambat optimalisasi pendapatan pajak hotel. Selanjtunya, Riastini, Sinarwati, \& Diatmika (2017) juga mengakaji penelitian serupa berjudul "Efektivitas dan Kontribusi Pajak Hotel dan Restoran di Kintamani Terhadap Pendapatan Asli Daerah Kabupaten Bangli Tahun 2011-2015”. Hasil penelitian ini menunjukkan bahwa, tingkat efektivitas pajak hotel dan restoran di Kintamani terhadap Pendapatan Asli Daerah Kabupaten Bangli tahun 2011-2015 kurang efektif, dimana analisis efektivitas yang dicapai yaitu tahun 2011 tingkat efektivitas yang dicapai sebesar 75.46\%, tahun $201270,68 \%$, tahun 2013 35,28\%, tahun 2014 65,59\%, dan pada tahun 2015 tingkat efektivitas yang dicapai sebesar $73,25 \%$. Sedangkan kontribusi yang diberikan oleh pajak hotel dan restoran terhadap Pendapatan Asli Daerah Kabupaten Bangli tahun 2011-2015 dalam kategori kecil, dimana hasil analisis kontribusi yang tercapai yaitu tahun 2011 hanya sebesar 1,24\%, tahun 2012 0,51\%, tahun 2013 0,49\%, tahun 2014 $0,47 \%$ dan pada tahun 2015 sebesar 0,36\%. Selain peniti di atas, Adnyana, Sumerthayasa, \& Suardita (2018) juga mengkaji penelitian serupa tentang "Efektivitas Peraturan Daerah Nomor 15 Tahun 2011 Tentang Pajak Hotel Di Kabupaten Bangli’'. Hasil penelitian ini menunjukkan bahwa pelaksanaan pajak hotel terhadap peningkatan pendapatan asli daerah, telah berjalan dengan baik, hanya saja untuk jumlah pajaknya masih kecil. Ini disebabkan oleh jumlah hotel yang ada di Kabupaten Bangli sedikit.

Berdasarkan latar belakang dan penelitian terdahulu di atas, penelitian ini bertujuan untuk mengetahui efektivitas Peraturan Daerah Kabupaten Bangli Nomor 15 Tahun 2011 tentang Pajak Hotel dan juga untuk mengetahui upaya peningkatan pendapatan asli daerah dalam pelaksanaan Peraturan Daerah Kabupaten Bangli Nomor 15 Tahun 2011 tentang Pajak Hotel.

\section{METODE PENELITIAN}

Penelitian ini menggunakan penelitian hukum empiris. Penelitian hukum empiris adalah penelitian berupa studi-studi empiris untuk menemukan teori-teori mengenai proses terjadinya dan mengenai proses bekerjanya hukum di dalam masyarakat. Penelitian ini menggunakan pendekatan Perundangundangan (The Statue Approach) dan pendekatan Fakta (The Fact Approach). Teknik Pengumpulan data yang digunakan dalam penelitian penelitian ini adalah teknik wawancara, teknik studi dokumen dan teknik observasi/pengamatan.

\section{HASIL DAN PEMBAHASAN}

\section{Efektifitas Peraturan Daerah Kabupaten Bangli Nomor 15 Tahun 2011 tentang Pajak Hotel}

Efektifitas pelaksanaan pemungutan pajak terhadap peningkatan pendapatan asli daerah dari suatu daerah, dapat diketahui kontribusi dari setiap sektor pajak sebagai pendapatan asli daerah. Berdasarkan data yang diperoleh dari Kantor Badan Keuangan, Pendapatan dan Aset Daerah Kabupaten Bangli, kontribusi dari setiap sektor pajak sebagai pendapatan asli daerah bisa terlihat pada tabel dibawah ini:

Tabel 1. Kontribusi Jenis Pajak terhadap Pendapatan Asli Daerah

di Kabupaten Bangli di Tahun 2017

\begin{tabular}{|c|l|l|l|l|}
\hline No & \multicolumn{1}{|c|}{ Jenis Penerimaan } & \multicolumn{1}{|c|}{ Anggaran (Rp) } & Realisasi (Rp) & $\%$ \\
\hline 1 & Pajak Hotel & 50.000 .000 .00 & 84.101 .819 .00 & 168.20 \\
\hline 2 & Pajak Restoran & 515.000 .000 .00 & 286.508 .292 .00 & 55.63 \\
\hline
\end{tabular}




\begin{tabular}{|c|l|l|l|l|}
\hline 3 & Pajak Hiburan & - & 750.000 .00 & - \\
\hline 4 & Pajak Reklame & 308.000 .000 .00 & 201.080 .393 .00 & 65.29 \\
\hline 5 & $\begin{array}{l}\text { Pajak Penerangan Jalan } \\
\text { PLN }\end{array}$ & 3.221 .812 .000 .00 & 3.815 .239 .787 .00 & 118.42 \\
\hline 6 & Pajak Air Bawah Tanah & 55.000 .000 .00 & 74.311 .032 .00 & 135.11 \\
\hline 7 & $\begin{array}{l}\text { Pajak Mineral Bukan } \\
\text { Logam dan Batuan }\end{array}$ & 800.000 .000 .00 & 1.027 .302 .000 .00 & 128.42 \\
\hline 8 & $\begin{array}{l}\text { PBB } \\
\text { Perdesaan \& Perkotaan }\end{array}$ & 2.600 .000 .000 .00 & 3.196 .381 .325 .00 & 119.86 \\
\hline 9 & BPHTB & 1.500 .000 .000 .00 & 3.196 .381 .325 .00 & 213.09 \\
\hline 10 & Jumlah & 9.0 .49 .812 .000 .00 & 11.802 .144 .519 .00 & 130,41 \\
\hline
\end{tabular}

Sumber: Badan Keuangan, Pendapatan dan Aset Daerah Bangli

Tabel 2. Kontribusi Jenis Pajak terhadap Pendapatan Asli Daerah di Kabupaten Bangli Tahun 2018

\begin{tabular}{|c|l|l|l|l|}
\hline No & \multicolumn{1}{|c|}{ Jenis Penerimaan } & \multicolumn{1}{|c|}{ Anggaran $(\mathrm{Rp})$} & \multicolumn{1}{c|}{ Realisasi (Rp) } & $\%$ \\
\hline 1 & Pajak Hotel & 65.000 .000 .00 & 73.130 .121 .00 & 112.51 \\
\hline 2 & Pajak Restoran & 365.000 .000 .00 & 241.887 .361 .00 & 66.27 \\
\hline 3 & Pajak Hiburan & - & 2.100 .000 .00 & - \\
\hline 4 & Pajak Reklame & 308.000 .000 .00 & 296.110 .883 .50 & 96.14 \\
\hline 5 & $\begin{array}{l}\text { Pajak Penerangan Jalan } \\
\text { PLN }\end{array}$ & 4.200 .150 .000 .00 & 4.425 .168 .935 & 105.36 \\
\hline 6 & Pajak Air Bawah Tanah & 70.000 .000 .00 & 86.388 .492 .00 & 123.41 \\
\hline 7 & $\begin{array}{l}\text { Pajak Mineral Bukan } \\
\text { Logam dan Batuan }\end{array}$ & - & - & - \\
\hline 8 & $\begin{array}{l}\text { PBB Perdesaan \& } \\
\text { Perkotaan }\end{array}$ & 3.000 .000 .000 .00 & 3.251 .373 .142 .00 & 108.38 \\
\hline 9 & BPHTB & 3.200 .000 .000 .00 & 4.181 .786 .225 .00 & 130.68 \\
\hline 10 & Jumlah & 11.208 .150 .000 .00 & 12.557 .945 .159 .50 & 112.04 \\
\hline
\end{tabular}

Sumber: Badan Keuangan, Pendapatan dan Aset Daerah Bangli

Tabel 3. Kontribusi Jenis Pajak terhadap Pendapatan Asli Daerah Kabupaten Bangli Tahun 2019

\begin{tabular}{|c|l|l|l|l|}
\hline No & \multicolumn{1}{|c|}{ Jenis Penerimaan } & \multicolumn{1}{|c|}{ Anggaran (Rp) } & \multicolumn{1}{|c|}{ Realisasi (Rp) } & \multicolumn{1}{c|}{$\%$} \\
\hline 1 & Pajak Hotel & 80.000 .000 .00 & 142.655 .151 .40 & 178.32 \\
\hline 2 & Pajak Restoran & 485.188 .000 .00 & 1.105 .581 .469 .60 & 227.87 \\
\hline 3 & Pajak Hiburan & 166.000 .00 & 3.500 .000 .00 & 2.108 .43 \\
\hline 4 & Pajak Reklame & 311.000 .000 .00 & 311.561 .599 .00 & 100.18 \\
\hline 5 & $\begin{array}{l}\text { Pajak Penerangan } \\
\text { Jalan PLN }\end{array}$ & 5.009 .942 .000 .00 & 4.948 .000 .052 .00 & 98.76 \\
\hline 6 & $\begin{array}{l}\text { Pajak Air Bawah } \\
\text { Tanah }\end{array}$ & 90.000 .000 .00 & 125.548 .285 .00 & 139.50 \\
\hline 7 & $\begin{array}{l}\text { Pajak Mineral Bukan } \\
\text { Logam dan Batuan }\end{array}$ & - & - & - \\
\hline 8 & $\begin{array}{l}\text { PBB Perdesaan \& } \\
\text { Perkotaan }\end{array}$ & 3.250 .000 .000 .00 & 3.819 .725 .729 .00 & 117.53 \\
\hline 9 & BPHTB & 3.700 .000 .000 .00 & 5.592 .253 .839 .00 & 151.14 \\
\hline 10 & Jumlah & 12.926 .296 .000 .00 & 16.048 .826 .148 .00 & 124.16 \\
\hline
\end{tabular}

Sumber: Badan Keuangan, Pendapatan dan Aset Daerah Bangli

Dilihat dari data tabel di atas dapat dinyatakan bahwa kontribusi pajak terhadap Pendapatan Asli Daerah tahun 2017-2019 sudah sesuai dan melebihi target dari yang ditargetkan pemerintah Kabupaten Bangli. Tetapi untuk pelaksanaan pemungutan Pajak Hotel terhadap peningkatan pendapatan asli daerah 
di Kabupaten Bangli masih kecil. Perhitungan potensi target dan realisasi pajak hotel Kabupaten Bangli sebagai berikut:

Tabel 4. Target dan Realisasi Pajak Hotel

Tahun 2017-2019 di Kabupaten Bangli

\begin{tabular}{|c|c|l|l|c|}
\hline No & Tahun & Target & \multicolumn{1}{|c|}{ Realisasi } & $\%$ \\
\hline 1 & 2017 & 50.000 .000 .00 & 84.101 .819 .00 & 168.20 \\
\hline 2 & 2018 & 65.000 .000 .00 & 73.130 .121 .00 & 112.51 \\
\hline 3 & 2019 & 80.000 .000 .00 & 142.655 .151 .40 & 178.32 \\
\hline
\end{tabular}

Sumber: Badan Keuangan, Pendapatan dan Aset Daerah Bangli

Dari data di atas bisa dilihat presentase pemungutan pajak hotel di Kabupaten Bangli yang dilaksanakan oleh Badan Keuangan, Pendapatan Aset Daerah Kabupaten Bangli tidak stabil, walaupun telah melebihi target yang ditetapkan pemerintah Kabupaten Bangli.

Pajak hotel merupakan pajak yang sistem pemungutannya adalah self-assessment system. Pengertian self-assessment system adalah suatu sistem pemungutan pajak yang memberi wewenang kepada wajib pajak untuk menentukan sendiri besarnya pajak yang terutang. Ciri- ciri sistem ini adalah:

a. Wewenang untuk menentukan besarnya pajak terutang ada pada wajib pajak sendiri;

b. Wajib pajak aktif, mulai dari menghitung, menyetor dan melaporkan sendiri pajak yang terhutang;

c. Fiskus tidak ikut campur dan hanya mengawasi (Samudra, 2015:168)

Sistem self-assessment ini umumnya diterapkan pada jenis pajak yang memandang wajib pajaknya cukup mampu untuk diserahi tanggung jawab untuk menghitung membayar dan melaporkan utang pajaknya sendiri. Dalam sistem self-assessment, menghitung sendiri artinya bahwa wajib pajak harus menghitung sendiri berapa besarnya pajak yang terutang yaitu dengan menerapkan tarif pajak terhadap jumlah dasar pengenaan pajak. Dengan kata lain dapat diartikan bahwa self-assessment adalah bahwa setiap wajib pajak harus memenuhi kewajiban perpajakannya tanpa harus menunggu surat ketetapan pajak dari pemerintah.

Menurut Bapak I Wayan Gede Ariawan selaku Kasubid Pendapatan, Penilaian dan Penetapan Pajak Lainnya di Kantor Badan Keuangan Pendapatan dan Aset Daerah Kabupaten Bangli di Kantor Badan Keuangan, Pendapatan dan Aset Daerah Kabupaten Bangli, mengemukakan bahwa saat ini pelaksanaan pajak hotel di Kabupaten Bangli menggunakan sistem self-assessment, Wajib pajak diberikan kepercayaan untuk menghitung, melaporkan dan membayar sendiri jumlah pajak yang terutang. Wajib pajak menggunakan surat pemberitahuan pajak daerah (selanjutnya disingkat SPTPD) untuk melaporkan perhitungan dan/atau pembayaran pajak, objek pajak dan/bukan objek pajak, dan/ harta dan kewajiban sesuai dengan ketentuan perundang-undangan perpajakan daerah. Tetapi jika dikemudian hari ada wajib pajak yang tidak melakukan kewajiban membayar pajak, tindakan yang dilakukan oleh pemerintah yaitu yang pertama memberikan Surat teguran atau Surat Peringatan sebagai awal tindakan pelaksanaan penagihan pajak dikeluarkan 7 (tujuh) hari sejak saat jatuh tempo pembayaran. Dalam jangka waktu 7 (tujuh) hari setelah tanggal Surat Teguran atau Surat Peringatan dikeluarkan, Wajib Pajak harus melunasi Pajak yang terutang. Apabila jumlah pajak yang harus dibayar tidak dilunasi dalam jangka waktu sebagaimana dalam Surat Teguran atau Surat Peringatan, jumlah pajak yang harus dibayar ditagih dengan surat paksa. Tetapi menurut Bapak I Wayan Gede Ariawan di Kabupaten Bangli belum bisa menerapkan penagihan menggunakan surat paksa, walaupun peraturan daerah tentang penagihan pajak dengan surat paksa sudah ada yaitu Peraturan daerah Kabupaten Bangli Nomor 4 Tahun 2014 Tentang Penagihan Pajak Dengan Surat Paksa. Ini dikarenakan di Kabupaten Bangli belum memiliki pejabat yang kompeten, kompeten dalam hal ini adalah pejabat yang memiliki sertifikat kompetensi. (Wawancara penulis pada tanggal 7 Pebruari 2020).

Dalam pelaksanaan pemungutan pajak hotel di Kabupaten Bangli yang sudah berjalan dengan baik, ada beberapa hambatan-hambatan yang dirasakan oleh dinas Badan Keuangan, Pendapatan, dan Aset Daerah Kabupaten Bangli. Tentu saja hambatan-hambatan yang di angap sebagai suatu evaluasi untuk lebih meningkatkan program kerja yang dimiliki oleh pemerintah Kabupaten Bangli.

Lebih lanjut, bapak I Wayan Gede Ariawan Kasubid Pendapatan, Penilaian dan Penetapan Pajak Lainnya, menjelaskan bahwa masih ada beberapa hambatan-hambatan dalam pelaksanaan pemungutan pajak hotel di Kabupaten Bangli seperti antara lain: 
1. Masih banyak wajib pajak yang belum mengerti tentang kewajibannya harus membayar pajak karena minimnya sosialisasi;

2. Wajib pajak hotel di Bangli relatif masih kecil artinya income hotel masih rendah sehingga pajak yang harus disetor relatif kecil juga;

3. Lokasi-lokasi hotel dan restoran di Kabupaten Bangli relatif jauh, sehingga sulit dijangkau, jadi jika petugas tidak datang ke lokasi otomatis wajib pajak tidak mau membayar pajak. (Wawancara penulis pada tanggal 7 Pebruari 2020).

Hukum menitikberatkan kepada pengaturan aspek manusia sebagai makhluk sosial dan aspek lahiriah manusia. Dilihat dari segi tujuannya, norma hukum diadakan dalam rangka mempertahankan bentuk kehidupan bermasyarakat sebagai modus survival. Meskiupun hukum adakalanya mengatur kehidupan manusia sebagai pribadi, pengaturan tersebut dimasukkan dalam rangka individu itu dalam berinteraksi dengan individu lainnya atau antara individu dan kelompok. Misalnya, orang memiliki hotel merupakan suatu yang bersifat pribadi tetapi juga diatur oleh hukum, hal ini berkaitan dengan perijinan mendirikan hotel dan perpajakannya (Marzuki, 2016:97).

\section{Upaya Peningkatan Pendapatan Asli Daerah dalam Pelaksanaan Peraturan Daerah Kabupaten Bangli Nomor 15 Tahun 2011 tentang Pajak Hotel}

Dalam upaya peningkatan pelaksanaan pemungutan pajak hotel di Kabupaten Bangli, pihak dari Badan Keuangan, Pendapatan dan Aset Daerah Kabupaten Bangli memiliki upaya-upaya tersendiri, menurut bapak Y. Basuki Mulyono selaku kabid Pajak Daerah lainnya, retribusi dan lain-lainnya pendapatan, upaya-upaya dari Badan Keuangan, Pendapatan dan Aset Daerah Kabupaten Bangli adalah:

1. Sosialisasi

Sosialisasi yang dimaksud adalah sosialisasi Peraturan Daerah Kabupaten Bangli Nomor 15 Tahun 2011 tentang Pajak Hotel. Sosialisasi ini dilakukan oleh pihak Dinas Badan Keuangan, Pendapatan, Aset Daerah Kabupaten Bangli dengan mendatangi wajib pajak atau mengadakan pertemuan di kantor Badan Keuangan, Pendapatan dan Aset Daerah Kabupaten Bangli. Hal ini dilakukan agar wajib pajak mengerti dan memahami arti penting membayar pajak guna meningkatkan pendapatan asli daerah Kabupaten Bangli.

2. Pemberian reward atau penghargaan

Pemberian penghargaan ini dilakukan oleh pihak Dinas Badan Keuangan, Pendapatan, Aset Daerah Kabupaten Bangli dengan tujuan agar wajib pajak meningkatkan ketaatannya dalam pembayaran dan pelaporan pajaknya. Selain itu, pemberian penghargaan oleh Dinas Badan Keuangan, Pendapatan dan Aset Daerah Kabupaten Bangli adalah untuk menghargai wajib pajak yang telah taat dalam membayar dan melaporkan pajaknya. Tujuan lain yang dimiliki oleh Dinas Badan Keuangan Pendapatan dan Aset Daerah Kabupaten Bangli yaitu, diharapkan dapat memberikan motivasi dan sebagai acuan kepada wajib pajak lainnya agar selalu tepat waktu membayar dan melaporkan pajak.

3. Rutin melakukan verifikasi terkait data wajib pajak

Verifikasi dilakukan untuk meminimalis ir kekeliruan terkait pemasukan data wajib pajak.Verifikasidilakukan oleh bidang pembukuan penerimaan pada Dinas Badan Keuangan, Pendaptan, dan Aset Daerah Kabupaten Bangli. Jika ada wajib pajak yang salah memasukan data, dan setelah di verifikasioleh bidang pembukuan penerimaan maka wajib pajak akan dihubungi oleh bidang pembukuan penerimaan agar wajib pajak dapat mengubah kekeliruan dalam pemasukan data tersebut. Setelah itu wajib pajak membuat surat permohonan untuk perihal perubahan data yang keliru (Wawancara penulis pada tanggal 10 Pebruari 2020).

Menurut bapak Y. Basuki Mulyono, untuk meningkatkan jumlah hotel yang sedikit karena di Kabupaten Bangli tidak boleh membangun hotel-hotel besar atau hotel berbintang sesuai peraturan daerah Provinsi Bali Tentang tata ruang, maka pemerintah Kabupaten Bangli bisa mendirikan Hotel dengan jumlah kamar kurang dari 20 kamar, selain itu pemerintah Kabupaten Bangli bisa membuat desa wisata, yaitu desa yang menyediakan rumah penginapan dengan bekerjasama dengan investor. Dan 
upaya yang dilakukan oleh badan keuangan, pendapatan dan aset daerah Kabupaten Bangli dalam mengatasi masih ada wajib pajak yang belum memiliki ijin tetapi sudah beroperasi, yaitu dengan mendatangi langsung kelapangan dan menagih pajaknya secara langsung, karena menurut bapak Y. Basuki Mulyono pajak merupakan kewajiban dari adanya jasa maka dari itu walaupun hotel tersebut belum mendapatkan ijin tetap akan di tagih pajaknya sesuai undang-undang dan peraturan daerah yang berlaku. Upaya- upaya ini dilakukan untuk meningkatkan Pendapatan asli daerah dari sector pajak hotel.

\section{SIMPULAN}

Berdasarkan pembahasan di atas, dapat disimpulkan bahwa 1) Efektifitas Peraturan daerah Kabupaten Bangli Nomor 15 Tahun 2011 tentang Pajak Hotel berdasarkan target realisasi pendapatan daerah Kabupaten Bangli telah berjalan efektif. Hasil ini dapat dilihat dari pencapaian target realisasi pajak di Kabupaten Bangli dalam 3 (tiga) tahun terakhir yaitu: a) Tahun 2017 dengan target 50.000.0000.00 realisasi 84.101 .819 .00 dengan persentase $168.20 \%$. b) Tahun 2018 dengan target 65.000 .000 .00 realisasi 73.130 .121 .00 dengan persentase $112.51 \%$. c) Tahun 2019 dengan target 80.000 .000 .00 realisasi 142.655 .151 .40 dengan persentase $178.32 \%$. 2) Upaya peningkatan pemungutan pajak hotel yang dilakukan oleh Badan Keuangan Pendapatan dan Aset Daerah kabupaten bangli yaitu yang pertama melakukan sosialisasi langsung ke masyarakat yang kedua memberikan reawed atau penghargaan kepada wajib pajak yang telah taat melakukan kewajibannya membayar pajak yang ketiga rutin melakukan verifikasi data wajib pajak, selain itu upaya yang dilakukan oleh pemerintah Kabupaten Bangli dalam meningkatkan pemungutan pajak hotel yaitu denganmengefektifkan pemungutan pajak menggunakan surat paksa agar pemungutan pajak hotel di Kabupaten Bangli semakin meningkat dan memberikan sanksi-sanksi kepada wajib pajak apabila tidak melakukan kewajibannya membayar pajak. Adapun saran yang dapat diberikan yaitu: 1) Dalam efektifitas peraturan daerah Kabupaten Bangli Nomor 15 Tahun 2011 tentang pajak hotel terhadap peningkatan pendapatan asli daerah Kabupaten Bangli badan keuangan, pendapatan dan aset daerah Bangli harus lebih meningkatkan pengawasan terkait pelaksanaan dan pembayaran pajak hotel tersebut, guna meningkatkan pendapatan asli daerah dikabupaten bangli. 2) Dalam meningkatkan upaya pemungutan pajak hotel di Kabupaten Bangli, Pemerintah kabupaten bangli harus lebih giat lagi melakukan promosi pariwisata yang ada di Kabupaten Bangli baik secara langsung ataupun melalui internet, selain itu hotel-hotel yang ada di kabupaten bangli harus meningkatkan pelayanan dan fasilitas yang ada di hotel tersebut agar wisatawan lebih banyak datang dan menginap di Bangli.

\section{DAFTAR PUSTAKA}

Adnyana, I. D. A. Y. T., Sumerthayasa, P. G. A., \& Suardita, I. K. (2018). Efektivitas Peraturan Daerah Nomor 15 Tahun 2011 Tentang Pajak Hotel Di Kabupaten Bangli. Kertha Negara: Journal Ilmu Hukum, 6(2), 1-5. $\quad$ Retrieved from https://ojs.unud.ac.id/index.php/Kerthanegara/article/view/38508/

Ardiles, A. (2015). Analisis Potensi Dan Kontribusi Pajak Hotel Terhadap Pendapatan Asli Daerah Pemerintah Kota Padang (Studi Kasus di Dinas Pengelolaan Keuangan dan Aset Kota Padang). $\begin{array}{llll}\text { Jurnal Akuntansi, } & \text { 3(1). } & \text { Retrieved }\end{array}$ http:/ejournal.unp.ac.id/students/index.php/akt/article/view/1637

Manus, F., Sabijono, H., \& Wangkar, A. (2015). Analisis Implementasi Peraturan Daerah Nomor 2 Tahun 2011 Tentang Pajak Hotel Kategori Rumah Kost di Kota Manado. Jurnal EMBA: Jurnal Riset Ekonomi, Manajemen, Bisnis Dan Akuntansi, 3(4). doi:https://doi.org/10.35794/emba.v3i4.10923

Marzuki, P. M. (2016). Pengantar Ilmu Hukum. Jakarta: Kencana.

Mertayasa, I. W. G., Suyatna, I. N., \& Sarna, K. (2017). Pelaksanaan Peraturan Daerah Kabupaten Badung Nomor 15 Tahun 2011 Tentang Pajak Hotel Dalam Rangka Meningkatakan Pendapatan Asli Daerah di Kabupaten Badung. Kertha Negara: Journal Ilmu Hukum, 5(3). Retrieved from https://ojs.unud.ac.id/index.php/Kerthanegara/article/view/31251

Pudyatmoko, Y. S. (2002). Pengantar Hukum Pajak. Yogyakarta: Andi.

Riastini, N. K. A., Sinarwati, N. K., \& Diatmika, I. P. G. (2017). Efektivitas dan Kontribusi Pajak Hotel 
dan Restoran di Kintamani Terhadap Pendapatan Asli Daerah Kabupaten Bangli Tahun 20112015. JIMAT (Jurnal Ilmiah Mahasiswa Akuntansi) Undiksha, 8(2). doi:http://dx.doi.org/10.23887/jimat.v8i2.10457

Samudra, A. A. (2015). Perpajakan di Indonesia (Keuangan, Pajak dan Retribusi Daerah). Jakarta: Rajawali Pers.

Setedi, A. (2008). Hukum Pajak dan Retribusi Daerah. Bogor: Ghalia Indonesia.

Sholihan, S., Kasmawanto, Z., \& Munir, A. (2017). Tinjauan Yuridis Peraturan Daerah Lamongan No.

12 Tahun 2010 Mengenai Pajak Daerah atas Pajak Restoran sebagai Upaya Peningkatan Pendapatan Daerah Lamongan. HUMANIS: Jurnal Ilmu-Ilmu Sosial Dan Humaniora, 9(2), 117126. Retrieved from http:/e-jurnal.unisda.ac.id/index.php/Humanis/article/view/360

Siahaan, M. P. (2010). Pajak Daerah \& Retribusi Daerah. Jakarta: PT. Raja Grafindo Persada.

Sujianto, \& Andrika. (2015). Implementasi Peraturan Daerah Nomor 07 Tahun 2011 Tentang Pajak Hotel (Studi Kasus Pajak Rumah Kos -Kosan Di Kecamatan Tampan). Jurnal Online Mahasiswa Fakultas Ilmu Sosial Dan Ilmu Politik Universitas Riau, 2(2). Retrieved from https://www.neliti.com/publications/32512/implementasi-peraturan-daerah-nomor-07-tahun2011-tentang-pajak-hotel-studi-kasu\#cite

Widyaningsih, A. (2011). Efektivitas Pemungutan Pajak Penerangan Jalan dan Kontribusinya Terhadap Pendapatan Asli Daerah Kota Bandung. Jurnal ASET (Akuntansi Riset), 3(1), 478. doi:10.17509/jaset.v3i1.10061

Yusmaniarti, E. (2017). Efektivitas Pelaksanaan Peraturan Daerah Kabupaten Melawi Tentang Pajak dan Retribusi Daerah dalam Menunjang Pendapatan Asli Daerah. Jurnal Nestor Magister Hukum, 4(4). Retrieved from http://jurnal.untan.ac.id/index.php/nestor/artic le/view/21052

Zulhuda, F. (2017). Kontribusi Pajak Hotel Terhadap Pendapatan Asli Daerah Kota Semarang. Journal of Politic and Government Studies, 6(4), 421-430. Retrieved from https://ejournal3.undip.ac.id/index.php/jpgs/article/view/17827 